University of Nebraska - Lincoln

DigitalCommons@University of Nebraska - Lincoln

Faculty Publications, Department of History

History, Department of

1980

\title{
A Good Prince: King John and Early Tudor Propaganda
}

Carole Levin

University of Nebraska - Lincoln, clevin2@unl.edu

Follow this and additional works at: https://digitalcommons.unl.edu/historyfacpub

Part of the History Commons

Levin, Carole, "A Good Prince: King John and Early Tudor Propaganda" (1980). Faculty Publications, Department of History. 50.

https://digitalcommons.unl.edu/historyfacpub/50

This Article is brought to you for free and open access by the History, Department of at DigitalCommons@University of Nebraska - Lincoln. It has been accepted for inclusion in Faculty Publications, Department of History by an authorized administrator of DigitalCommons@University of Nebraska - Lincoln. 


\section{A Good Prince: King John and Early Tudor Propaganda Carole Levin* Arizona State University}

EXCEPT FOR A CERTAIN period during the English Reformation-an exception that supplies the topic for the following paragraphs - King John has been despised with near unanimity for centuries. His poor reputation began early: soon after his death the chroniclers recalled him as a young prince habitually plotting against his brother Richard (who forgave him each time with suave contempt), and as an arbitrary king who vexed his own nobles into civil war. They remembered his stamping rages and appalling cruelties, his sloth, his gluttony; and they accused him of lechery so befuddling that once he lay in bed all morning with his young new wife while his army floundered to a defeat in the field. ${ }^{1}$ And since the chroniclers were churchmen, they remembered John's sullen defiance of Pope Innocent III with special clarity. In 1206 he rejected Stephen Langton as archbishop of Canterbury, even though Innocent himself had designated him for the post. When negotiations over Langton failed, Innocent placed the whole of England under papal interdict, a favorite sanction of his. ${ }^{2} \mathrm{John}$ ignored this prod, and Innocent took the further step of excommunicating him. John ignored this also. At length, however, when the French threatened to invade, John capitulated. Not only did he accept Langton but also yielded his kingdom to Innocent as a papal fief. He did so as a matter of policy, to gain the pope's support against France, a move that many of his nobles thought so astute that they tried to claim credit for thinking of it. ${ }^{3}$ To others, of course, John's behavior looked like abject hysteria, proving him cowardly as well as impious.

This view of John as a coward, a bully, and a voluptuary would last for centuries; indeed it may still be the consensus that John is the worst monarch to rule England. For a time, however, during the advent of the English Reformation and for some years afterward, John's reputation underwent - at least officially - a complete rehabilitation: the medieval villain became a hero of English liberty, a kind of anticipant Protestant, a lonely pioneer in resisting the tyrannies of Rome.

* A shorter version of this paper was presented at the third Ohio Conference on Medieval and Renaissance Studies, October 12, 1976.

${ }^{1}$ See for example Roger of Wendover's Flowers of History, Comprising the History of England from the Descent of the Saxons to 1235, translated by J. A. Giles (2 vols.; London: Bohn, 1849) and Flowers of History, especially such as Relate to the Affairs of the World to the Year 1307, Collected by Matthew of Westminster, translated by C. D. Yonge (2 vols.; London: Bohn, 1853).

${ }^{2}$ H. G. Richardson and G. O. Sayles, The Governance of Medieval England from the Conquest to the Magna Carta (Edinburgh: Edinburgh University Press, 1963), p. 344.

${ }^{3}$ W. L. Warren, King John (London: Eyre and Spottiswoode, 1961), p. 210. 
John's principal benefactor in this project was Thomas Cromwell, Henry VIII's chief minister and the coordinator of a vast campaign of propaganda designed to reconcile Englishmen to their new religious way of life. Many historians attribute the successful planting of Henry's church to Cromwell's efforts, which were thorough and shrewd. ${ }^{4}$ Certainly Cromwell as a propagandist was aware of the delightful plasticity of history. According to Cromwellian propaganda, for example, Henry II played no part in the death ("which they untruly call martyrdom") of England's most cherished saint, Thomas à Becket. In Cromwell's revised version Becket, on the night he died, was bickering with the archbishop of York over jurisdiction. Their quarrel led to a riot outside the church in Canterbury. Becket jeered at his rival's followers, calling one a "bawd;" and when he began to manhandle another of them he was cut down by the victim's friends. ${ }^{5}$ This transformation of Chaucer's "holye blisful martyr" into a sort of street thug is a mark of Cromwell's pragmatic zeal, which did not quaver in the face of the facts.

Similarly, John's struggle with his pope could serve as a useful precedent to Henry's, making it seem less irreverent of tradition, so long as certain inconveniences were expunged from the record and John were made presentable. Luckily this process had begun before Cromwell even needed it; for in fact he and his propagandists never invented the heroic John, but only adopted him. The transforming of John had begun in the late 1520s, back when England was still Catholic and its monarch was still Defender of the Faith, and those who ran too far ahead on the path that officialdom would later take itself were well advised to keep running.

William Tyndale, for example, the exiled heretic, in his most important original work, The Obedience of a Christian Man (1528), directs us to

4 There are many works discussing Henry VIII and Cromwell's role in persuading the English people to accept the Reformation. A. F. Pollard is one of the school of thought that the English fundamentally supported the Reformation. See his Henry VIII (London: Longman's, Green, 1905), p. 430. Some other historians who hold this view are H. A. L. Fisher, The History of England from the Accession of Henry VII to the Death of Henry VIII, 1485-1547 (London: Longman's Green, 1906), p. 342; J. D. Mackie, The Earlier Tudors, 1485-1548 (Oxford: University Press, 1952), p. 335; W. Gordon Zeevelt, Foundations of Tudor Policy (Cambridge: Harvard University Press, 1948), pp. 6, 7. Other historians argue that Henry's program was highly unpopular and imposed through coercion. They include: James Gairdner, ed., Letters and Papers Foreign and Domestic of the Reign of Henry VIII (London: H.M.S.O., 1888), VIII, xxxii; Roger B. Merriman, Life and Letters of Thomas Cromwell (2 vols.; Oxford: the Clarendon Press, 1902), I, 85, 85-88; John Green, History of the English People (4 vols.; New York: Harper Brothers, n.d.), II, 160; Abbe Constant, Reformation in England, trans. by the Rev. R. E. Scantlebury (2 vols.; London: Sheed and Ward, 1939), I, 296. The work most directly related to this question is Geoffrey Elton, Policy and Police: the enforcement of the Reformation in the age of Thomas Cromwell (Cambridge: University Press, 1972), p. 3. See also Pierre Janelle, L'Angleterre Catholique à la Veille du Schisme (Paris: Beauchesne, 1935), p. 132; A. J. Slavin, Thomas Cromwell on Church and Commonwealth: Selected Letters, 1523-1540 (New York: Harper and Row, 1969), p. xxi; Arthur B. Ferguson, The Articulate Citizen and the English Renaissance (Durham, North Carolina: Duke University Press, 1965), p. 134; and Francis Gasquet, Henry VIII and the English Monasteries: an attempt to illustrate the history of their suppression (2 vols.; FLondon: Hodges, 1893), I, 313.

${ }^{5}$ Elton, Policy and Police, p. $257 \mathrm{nl}$. 
"Read the story of King John, and of other kings," if we would know how subversive the Catholic church has been to the authority of rightful kings. "They will have their cause avenged," he vows, "though realms shall therefore perish." John's case was particularly unjust. In Tyndale's account the pope lays down the interdict when John quite rightly attempts to punish a clerk for coining false money. "The laymen that had not done half great faults must die, but the clerk must go escape free!" Having gained this inequity, the Pope proceeds under a kind of evil momentum to encourage the French king to invade John's realm, promising his prior remission of sins for "murdering for the pope's pleasure." Under this threat John surrenders his kingdom as a fief to the papacy. ${ }^{6}$ In this account of a much-injured, blameless, and stoic John, Tyndale may be guilty of a deliberate contrivance, hoping to blacken the pope by means of a contrast with his victim. A less severe interpretation is also possible. W H. Lewis has remarked on a tendency, perhaps uniquely English, to assume that a man is a good fellow simply because he has been made to suffer $;^{7}$ and perhaps this kind of sympathy lies behind Tyndale's depiction of John as an innocent perversely victimized. Still another possibility is that Tyndale in his exile, powerless himself but willing the perishing of realms, isolated in behalf of a career that has been said to show "a stark independence of groups, fashions, and hero-worship,"8 allowed himself a sense of companionship with John, finding his own efforts vindicated in the apparently similar struggles of a man centuries before. Tyndale does seem to project some of his own motives on John in another of his works, Tribulation, where he asserts that John would (had his nobles given him the help he deserved), have "put a good and godly reformation in his own land!"' - a far more ambitious project than the punishing of one counterfeiter.

A similar account of John as a righteous man heinously persecuted appears in Simon Fish's Supplication of the Beggars (1528). Here the pope is said to have laid down the interdict because John tried to punish some traitors who conspired with the French crown to depose him. The interdict leads to John's surrender of the kingdom; and ever since then England "wrongfully (alas for shame) has stood tributary . . . unto a cruel, devilish blood-supper drunken in the blood of the saints and martyrs of Christ. . . ." Like Tyndale, Fish draws a vehement contrast between the persecuting clergy and its innocent victim: "Here were an holy sort of prelates that thus cruelly could punish such a righteous king, all his realm and succession, for doing right!" Fish insists upon it: John suffered "for no other cause but for his righteousness." The

\footnotetext{
${ }^{6}$ William Tyndale, Doctrinal Treatises, edited by Henry Walter (Cambridge: University Press, 1848), pp. 249, 338.

' W. H. Lewis, The Splendid Century (Garden City, New York: Doubleday, 1957), p. 223.

${ }^{8}$ A. G. Dickens, The English Reformation (New York: Schocken, 1964), p. 70.

${ }^{9}$ Rev. Greenslade, ed., The Works of William Tyndale (London and Glascow: Blackie, 1938), p. 211. (STC no. 24446)
} 
only reason Fish saw that John made himself the pope's liegeman was that since the churchmen connived with the French to attack England, there would be great bloodshed unless John gave in. "This good and blessed king of great compassion, more fearing and lamenting the shedding of the blood of his people than the loss of crown and dignity against all right and conscience. . . . O case most horrible that ever so noble a king, realm, and succession should thus be made to stoop to such a sort of blood suppers." 10

Written from exile in the Low Countries, the Supplication was brought secretly to London; possibly Anne Boleyn gave a copy to Henry VIII. ${ }^{11}$ If so, then it reached its intended audience since Fish wrote his Supplication as if it were a plea to Henry VIII from the beggars of England, who are being elbowed aside by those more ambitious beggars, the Catholic clergy. Fish intended his pamphlet to be read by the common people as well as by the king, and he succeeded. Just before the assembling of Parliament, "London was flooded with copies of it, in a way which suggests the connivance of someone in authority." 12

Fish's attack on the avarice of the church was largely invention and exaggeration, but not entirely. The following remark, for instance, came from the pulpit: "I say, he that give or offers one penny to St. Thomas's shrine, it is more meritorious for the soul than he had given a noble to poor people, for one is spiritual and the other corporal."13 If a preacher could say that, then it is certainly understandable that the Supplication could gather a following.

In fact it enjoyed so enormous a success that it provoked a rebuttal from one of the most eminent Catholic humanists in England, Thomas More, who was at that time chancellor of England. Fish had written from the point of view of the needy beggars in England; More responded from the point of view of the poor souls in purgatory. It is significant that More's Supplication of the Souls, though a detailed response, omits any mention of John in this context - which suggests that Fish had succeeded in drawing a parallel between Henry VIII and John, so that to be anti-John was to be disloyal. ${ }^{14}$

To draw a parallel between Henry and John, as Fish had done, was all very well so long as one had in mind the right version of John. A survey of the seditious comment reported to Cromwell in the 1530s, however, shows that some drew the wrong parallel, comparing Henry to the villainous John of the chronicles. William Inold, for instance, a priest in Rye, warned his flock that

${ }^{10}$ Supplication of the Beggars in William Huse Dunham, Jr., and Stanley Pargellis, editors, Complaint and Reform in England (New York: Oxford University Press, 1938), pp. 89- 90. (STC 10883)

"Sir Leslie Stephen and Sir Sidney Lee, editors, The Dictionary of National Biography (London: The Oxford University Press, 1963-64), VII, 51-52.

12 Ibid.

${ }^{13}$ Dickens, The English Reformation, p. 101; Letters and Papers, VII, 480.

${ }^{14}$ Thomas More, Supplication of the Poor Souls in Purgatory, ed. by Sister Mary Thecla (Westminster, Md.: Newman, 1930). pp. 38-39. (STC 18092 and 18093) 
Henry's defiance of Rome endangered them; for there was a precedent: "What misery were the people of this realm in by the days of King John, who standing accursed by the pope, there was neither corn, grass, nor fruits growing within this realm!" Unconvinced, one of the congregation answered: "As for the pope's curse it is but words, and it is thought that no like effect will follow in our days." Even so, Inold's rhetoric worried his examiner, who concluded his report with a warning: "so are the common people seduced and brought into murmuring." 15

Even more dangerous was the comment of the clerk John Hale in 1535, who "beseeched God" that Henry might die - that his death "may be like the death of the most wicked John, sometime King of this realm, or rather to be called a great tyrant than a king." 16 In fact John had died of natural causes, probably dysentery, but Hale had a different fate in mind. He and his contemporaries had read another version of John's death, an invention of medieval chroniclers. John, it was said, had conceived a plan to inflate the price of grain for his own profit; hearing of this plan, a certain patriotic monk contrived to share a goblet of poisoned wine with John, sacrificing his own life to rid England of a tyrant. Hale's remark, then, was open incitement to killing the king, and it is no wonder that he was judged a traitor and executed.

That statements like Hale's were current showed the necessity of promoting a positive view of John. Tyndale and Fish had provided such a view; and Cromwell had men in his employ who were eager to exploit it.

One such man was Robert Barnes. Though his Supplication to Henry VIII was written in the 1530 s under Cromwell's patronage, in some ways his background, his ideals, and his willingness to attack the "whore of Babylon" on his own initiative align him with Tyndale and Fish. Like them, he had found England in the 1520s inhospitable to a man of his convictions. In 1528 he fled to Antwerp, after artfully making it appear that his studies had driven him mad and he had drowned himself. In 1531 Cromwell invited him to return to England. From that time forward their lives were closely connected. Barnes not only wrote for Cromwell but was sent on diplomatic missions, including the ill-fated one to Cleves. He was executed only two days after Thomas Cromwell's execution. ${ }^{17}$

To the second edition of Barnes's Supplication (1534) some historical examples were added, possibly at Cromwell's direction, to demonstrate more vividly the dangers of a Catholic fifth column. ${ }^{18}$ Addressing the English clergy, he remarks, "I am sure you do remember how obediently you drove

${ }^{15}$ Letters and Papers, XIII, 658.

${ }^{16}$ Ibid., p. 609.

17 Dictionary of National Biography, I, 1173-76.

${ }^{18}$ F. J. Levy, Tudor Historical Thought (San Marino: The Huntington Library, 1967), p. 88; Rainer Pineas, "Robert Barnes' Polemic Use of History," Bibliothèque d'Humanisme et Renaissance, XXVI (1964), 55-69. 
Kynge John out of his kingdom.” This expulsion of John - entirely Barnes's invention - began when four English bishops refused to pay taxes in support of John's Irish wars. Having finally subdued the Irish, John turned his attention to these bishops and confiscated some of their property. To retaliate, the pope excommunicated John, put England under an interdict, and promised England to the Dauphin. John had to flee the Wales until "he was content to make agreement" with the pope, who forced him to pay a great sum to the four bishops and to the papal legate, to pay the pope another great sum annually, and to make England a papal fief. Barnes may well have chosen his examples hastily; for they tend to run counter to his purpose. He has John quarreling with his bishops over money when a bit more invention could provide a more noble matter of dispute, such as religious freedom; and when he recounts the old story of John's poisoning by a monk, he follows the medieval explanation for the crime: that John intended to inflate the price of a halfpenny loaf to twenty shillings. Though the monk's initiative rescues his countrymen from penury, Barnes refers to him as "a devyll" and contrives for him the standard papistical cynicism of asking his abbot for absolution in advance; and John, in spite of his extortionate plan, is "this good king," an "honorable king." 19 Though these incongruities tend to enfeeble the book, it was well thought of in official quarters. In a letter to Cromwell in May 1536, Bishop Longland praises its "charity and discretion," though it is hard to find either of these in Barnes's work. ${ }^{20}$

Another of the confirmed Protestants on the fringe of Cromwell's circle was Miles Coverdale, who met Cromwell in the 1520 s and found him "afterwards a powerful friend." ${ }^{21}$ Coverdale's name appears under the dedication to Henry VIII of a folio volume of the Bible in English brought out by a foreign publisher in 1535. One theme of this dedication is the evil tendency of popes to seek political powers. Among the victims of their ambition was King John, one of Henry's "noble predecessors": "Whose heart would not pity it, yea, even with lamentation, to remember but only the intolerable wrongs done [to John] by the anti-christ of Rome." These injuries, says Coverdale, are "manifest in the chronicles," 22 though of course the chroniclers who recorded them easily refrained from lamenting.

Still another who referred to the unjustified suffering of John was William Barlow, "a feeble enthusiast,"23 who changed his conscience to the prevailing season. Barlow was successively bishop of St. Asaph, St. David's, (STC 1470)

19 Barnes, A Supplication Unto Henry VIII (2nd edn.; London: Bydell, 1534, no page).

${ }^{20}$ Letter and Papers, X, 804, p. 339.

21 Dictionary of National Biography, IV, 1289-1297.

${ }^{22}$ John Strype, Annals of the Reformation (a new edn.; 6 vols.; New York: Franklin, 1966), II, Part II, p. 492.

${ }^{23}$ James A. Froude, The History of England from the Fall of Wolsey to the Defeat of the Spanish Armada (12 vols.; London: Longman's Green, 1872), II, 341. 
Bath and Wells, and Chichester. An opponent of Wolsey's in the 1520s, he wrote tracts against him that were prohibited. Barlow soon renounced the errors of these tracts and wrote piteously to Henry VIII, imploring pardon for his attacks on Wolsey and the church. Perhaps because of his malleable personality, Barlow became a favorite at court and was attached to an embassy to France and Rome in 1529-1530. In 1531 he belatedly jumped on the orthodox bandwagon with an anti-Lutheran tract; but by 1535 he was a zealous reformer and was sent on an embassy to Scotland. There he attempted to convert James $\mathrm{V}$ to his uncle's way of thinking. Barlow put forth all the arguments he could muster, including historical ones. "Many excellent princes like John and Henry II of England were crully vexd," said Barlow, adding, "The bishop of Rome has now even put himself in God's place." Despite Barlow's hope that James would "consider these things and Henry's desire to allure him to the 'favorable embracement of God's word,' "24 James was not convinced.

In Cromwell's propaganda effort, as in most such enterprises, we discover a high degree of humorless functionalism; a use is found for things of an apolitical nature and they are forced to bear a ponderous didactic weight. Richard Morison, one of Cromwell's men, complained of the popularity of Robin Hood plays, which were not only "lewd and ribald" but taught the people disobedience. He wanted these plays replaced by others that demonstrated the pope's wickedness and taught obedience to the king. Morison's program exhibits a curious blend of naivete and cynicism: people are assumed to confound their fantasy lives and their workaday realities with infantile readiness; and this is useful. Indeed Morison considered plays more effective than sermons, on the condescending principle that "into the common people things sooner enter by the eyes than by the ears." ${ }^{25} \mathrm{John}$ Bale, who enjoyed the favor of Cromwell and produced a number of anti-papal interludes, of which King John is one, comes the closest to fulfilling Morison's intentions.

Bale, educated at Cambridge, was a Carmelite monk. His conversion, though complete, was rather later than some of the other reformers. He became a Protestant around 1535, but the information about the time and circumstances are not completely clear. He began writing strongly Protestant plays in the 1530s, and for a time was under the patronage of the Earl of Oxford. A thoroughly contentious man, Bale was brought before Bishop Stokesley in London on the charge of heresy in 1536. Luckily for Bale, Thomas Cromwell intervened and saved him. Bale himself later testified that Cromwell protected him from his enemies on account of his plays. ${ }^{26}$

24 Letters and Papers, IX, 730.

${ }^{25}$ B. M. Royal MS 18, H.I in Elton, Policy and Police, p. 185.

${ }^{26}$ Jessie W. Harris, John Bale: A Study in the Minor Literature of the Reformation (Urbana: University of Illinois Press, 1940), p. 28. 
Bale had a troupe of five actors, known as "my Lord Cromwell's players," who toured England putting on Bale's plays. King John was written before 1536, and revised and presented at Archbishop Cranmer's house at Christmas season, 1538. In 1540, with the fall of Cromwell, Bale's theatrical career ended and he fled abroad. His plays were performed again at various times but never as part of a great and well-planned program. Bale, however, never lost faith in plays as effective propaganda. ${ }^{27}$

King John is important for a variety of reasons. Dramatically it is a link between the old morality plays and the new style of play to come later in the century. It is also the first play to present an English king on stage ${ }^{28}$ Most important for this study, however, is its theme. Strongly nationalistic, the play glories in the good king, who is fighting the Catholic church, represented on stage as two intriguers named Sedition and Dissimulation. David Bevington does point out that though John is named in the play, for nearly one-quarter of the drama John is removed from his historical setting and becomes "An essentially nameless English king" who is fighting for his church. ${ }^{29}$ Dramatically this works since his problems thus are the more identifiable as contemporary to the audience. This dramatic device does not suggest that Bale did not think well of the historic King John since he praises him in three of his prose works as well. ${ }^{30}$

The plot, such as it is, can be stated briefly. England, presented allegorically as a widow, begs the king to protect her against the church, who is pillaging her. John comes to her aid even though his nobility is fickle and the commonality poor and blind. The pope places an interdict on England and supports a French invasion. John backs down, but only to spare Englishmen from dying. In the matter of John's death, Bale puts a new twist on the old story of a poisoning monk. Dissimulation plots to murder John; and knowing that he must contrive a justification to public opinion, he tells Sedition:

And thys must thu saye to colour with the thynge,

that a penye lofe he wolde have brought to a shyllynge.

Sedition scoffs, "Naye, that is such a lye as easily wyll be felte." But Dissimulation replies, "Among fooles it never syll be out smelte.",31

At the critical moment, Dissimulation blunders: he so praises the drink that the generous John insists that the two of them share it. Unwilling to abandon his evil purpose, Dissimulation drinks his share. John does the same, and with his dying breath explains his philosophy:

27 Ibid.

${ }^{28}$ Ibid., p. 64.

${ }^{29}$ David Bevington, Tudor Drama and Politics: A Critical Approach to Topical Meaning (Cambridge: Harvard University Press, 1968), p. 99.

${ }^{30}$ Yet a Course at the Romyshe Foxe (Zurik: O. Jacobson, 1534) (STC 1309); A Declaration of E. Bonners Articles (London: T. Tysdall F. Cloldocke, 1561) (STC 1289); The Pageant of Popes, trans. into English by I.S. (London: T. Marshe, 1574) (STC 1304).

${ }^{31} \mathrm{John}$ Bale's King Johan, ed. with an introduction and notes by Barry B. Adams (Sam Marino: The Huntington Library, 1969), p. 129. 
Of priests and monkes I am counted a wycked man,

For that I never buylte churche nor monasterye,

But my pleasure was to helpe such as were nedye. ${ }^{32}$

Despite John's death the play ends happily. Imperial Majesty appears on stage representing the Tudor monarch Henry VIII, who will finish what John started and thus save England.

Around Christmas of 1538 John Alforde saw an interlude concerning King John at the home of Cranmer, which was most probably Bale's play. ${ }^{33}$ The play so impressed Alforde that at the house of Thomas Browne, who also saw it, he remarked "that it was a pity the bishop of Rome should reign any longer, for he would do with our King as he did with King John." Not everyone who heard this avowal was immediately convinced, and Henry Totehill replied "it was a pity and naughtily done to put down the Pope . . . for the Pope was a good man." Browne retorted that what he had seen at my lord of Canterbury's was "one of the best matters that ever he saw touching King John . . . and as far as he perceived King John was as noble a prince as ever was in England." Brought before an examiner, Totehill admitted that he had been drunk and said he "was sorry if he done amiss, for he thought no harm to any man." Apparently nothing was done to him. We can see, however, how thoroughly Alforde and Browne accepted the revised view of John.

Following Henry's reign this heroic view of John declined, though there are still examples of positive comments about John into the seventeenth century. The strongest positive view of John in the Elizabethan period is in John Foxe's Book of Martyrs. ${ }^{34}$ Even here, however, though John is a good king, he is not always a strong one. As John Elson puts it, Foxe treats King John with consistent sympathy, but not consistent admiration. ${ }^{35}$ This view of John emerges in the play The Troublesome Reign of King John as well, since the anonymous author probably used Foxe as a source. ${ }^{36}$ Holinshed's Chronicles, also enormously popular in the Elizabethan age, is rather negative in its portrayal of John, despite its anti-Catholic bias. ${ }^{37}$ Another popular history, Richard Grafton's A Chronicle at Large, demonstrates some of the confusion about John in the Elizabethan period. While much of the chapter on John comes straight from Foxe, Grafton used a fifteenth-century chronicle very

${ }^{32}$ Ibid., p. 132.

${ }^{33}$ Letters and Papers, XIV, 47.

${ }^{34}$ The Acts and Monuments of John Foxe: With a Life of the Martyrologist and Vindication of the Work, ed. by Rev. George Townsend (new edn.; 8 vols.; New York: AMS Press, 1965), II, $321-40$.

${ }^{35}$ John Elson, "Studies in the King John Plays," in Joseph Quincy Adams Memorial Studies, ed. by James G. McManaway, Giles Dawson, and Edwin Willoughby (Washington: The Folger Library, 1948), pp. $183-197$.

${ }^{36}$ The Troublesome Reign of King John, ed. by F. J. Furnivall and John Munro (Londit,11: Chatto and Windus, 1913). Elson points out the similarities between the two works.

${ }^{37}$ Holinshed's Chronicles of England, Scotland, and Ireland, ed. by Sir Henry Ellis (new edn.; 6 vols.; New York: AMS Press, 1965), II, 229339. 
hostile to John as his source for John's death, explaining that John was murdered because of his tyrannical behavior. ${ }^{38}$

The portrayals of John in the Elizabethan period, though far more sympathetic than the medieval chronicles, still show a king who is flawed. ${ }^{39}$ During the Elizabethan period the propaganda value of John's reign had shifted: rebellion was wrong, even if the king, like John, was not perfect. This point is made, for example, in the Homily Against Wilful Rebellion issued in 1570. ${ }^{39}$

One reason for this shift in the perception of John may be the changing nature of English Protestantism in the sixteenth century. The original champions of John belonged to the school of Wycliffe and Luther, who affirmed the rights of lay lords over the church and preached obedience to civil authority. They would naturally esteem John for his struggle to gain the right to appoint his own archbishop without papal interference. But when Mary assumed the throne and tried to renew English Catholicism, Protestants had to abandon their belief in non-resistance to authority. And when Elizabeth succeeded Mary, the zealots of Protestantism now were the Puritans - followers not of Luther but of Calvin. They spent their time telling Elizabeth that the sovereign was not omnipotent in church affairs; and they would tend to disfavor any ruler, like John, who interfered in them too heavily.

But really the decline of John's new reputation may be said to have begun in 1540, when its chief supporter, Thomas Cromwell, was accused of treason. Though never particularly known for his courage, Cranmer was so upset by Cromwell's arrest that he felt moved to write Henry in his support. In his letter he refers to the new view of John that Cromwell's patronage did so much to foster. Said Cranmer, Cromwell "was such a servant in my judgment, as no prince in this realm ever had. . . . If the noble princes of memory, King John, Henry the Second, and Richard II had had such a counsellor about them, I suppose that they should never have been so traitorously abandoned, and overthrown as those good princes were." 40 John was a "good prince" who had been overthrown. This had become the acceptable view of John, but its invocation was of no help to Cromwell, who in due course was condemned, brought to the scaffold, and executed.

\footnotetext{
${ }^{39}$ Richard Grafton, A Chronicle at Large and meere history of the affayres of England ... to the first yeere . . of Queen Elizabeth, standard edn. by Henry Ellis (London: Printed for J. Johnson, 1809), pp. 231, 232.

${ }^{39}$ An excellent discussion of this as it relates to Shakespeare's King John is by John Elliot, "Shakespeare and the Double Image of King John," Shakespeare Studies, I (1965), 64-84.

${ }^{40} \mathrm{~J}$. Griffiths, ed., The Two Books of Homilies to be read in Churches (Oxford: University Press, 1859), pp. $593-95$.

${ }^{41}$ The Remains of Thomas Cranmer, D.D. Archbishop of Canterbury, collected and arranged by the Rev. Henry Jenkyns, M.A. (4 vols.; Oxford: University Press, 1833), I, 299.
} 